\title{
Uji daya mesin diesel dengan hot EGR menggunakan bahan bakar campuran biosolar, metanol kadar rendah, dan jatropha
}

\author{
Yafid Effendi ${ }^{*}$, Syaiful ${ }^{2}$ \\ Program Studi Teknik Mesin, Fakultas Teknik, Universitas Muhammadiyah Tangerang ${ }^{1}$ \\ $\mathrm{Jl}$. Perintis Kemerdekaan I/33 Cikokol-Tangerang \\ Jurusan Teknik Mesin, Fakultas Teknik, Universitas Diponegoro² \\ JI. Prof. H. Soedarto, SH, Tembalang, Semarang 50239 \\ *Corresponding author: yafid_effendi@yahoo.com
}

\begin{abstract}
Motorized vehicles that are very suitable for transportation and heavy equipment vehicles are diesel engines, because their high combustion efficiency, reliability, fuel flexibility, and low fuel consumption make diesel widely used in several countries. The purpose of this study was to determine the effect of using a mixture of biosolar fuels, low levels of methanol and jatropha on power in a diesel engine using the hot Exhaust Gas Recirculation (EGR) system. This study uses an experimental method, using a 4JB1 diesel engine, the percentage of biodiesel fuel mixture, low levels of methanol and jatropha, Low Purity Methanol has a moisture content of $24.88 \%$. The ratio of biosolar mixture, methanol and jatropha used are D85LPM5J10, D80LPM10J10, D75LPM15J10, D75LPM5J20, D70LPM10J20, D65LPM15J20, D65LPM5J30, D60LPM10J30 and D55LPM15J30. EGR openings vary from $0 \%, 25 \%, 50 \%, 75 \%$ and $100 \%$. The test is carried out at a constant speed of 2000 rpm and is given a load of 25\%, 50\%, 75\% and 100\%. This study uses a dynamite brand Land \& Sea dynamite. The results of this study are the use of EGR resulted in increasing the value of brake power. The effect of the fuel mixture causes the value of brake power tends to fall compared to D100. When using D85LPM5J10, D80LPM10J10, D70LPM10J20 and D55LPM15J30 at low loads $(25 \%)$ there is an increase in power by $12.03 \%, 7.50 \%, 5.01 \%$, and $5.97 \%$.
\end{abstract}

Keywords: Power, Engine, Diesel, LPM, Jatropha, EGR.

\begin{abstract}
Abstrak
Kendaraan bermotor yang sangat sesuai untuk transportasi dan kendaraan alat berat adalah mesin diesel, karena efisiensi pembakaran yang tinggi, kehandalan, fleksibilitas bahan bakar, dan rendahnya konsumsi bahan bakar membuat diesel banyak digunakan di beberapa Negara. Tujuan penelitian ini adalah untuk mengetahui efek penggunaan campuran bahan bakar biosolar, methanol kadar rendah, dan jatropha terhadap daya pada mesin diesel menggunakan sistem hot Exhaust Gas Recirculation (EGR). Penelitian ini menggunakan metode eksperimen, menggunakan mesin diesel 4JB1, prosentase campuran bahan bakar biosolar, metanol kadar rendah, dan jatropha, Low Purity Methanol (LPM) mempunyai kadar air 24.88\%. Rasio campuran biosolar, metanol, dan jatropha yang digunakan adalah D85LPM5J10, D80LPM10J10, D75LPM15J10, D75LPM5J20, D70LPM10J20, D65LPM15J20, D65LPM5J30, D60LPM10J30 dan D55LPM15J30. Bukaan EGR divariasikan dari $0 \%, 25 \%, 50 \%, 75 \%$ dan $100 \%$. Pengujian dilakukan pada putaran konstan $2000 \mathrm{rpm}$ dan diberi beban dari 25\%, 50\%, 75\% dan 100\%. Penelitian ini menggunakan dynamometer merk dynamite Land \& Sea. Hasil dari penelitian ini adalah Pengunaan EGR mengakibatkan meningkatkan nilai brake power. Pengaruh campuran bahan bakar menyebabkan nilai brake power cenderung turun dibandingkan D100. Ketika menggunakan D85LPM5J10, D80LPM10J10, D70LPM10J20 dan D55LPM15J30 pada beban rendah (25\%) terjadi kenaikan daya sebesar $12.03 \%, 7.50 \%, 5.01 \%$, dan $5.97 \%$.
\end{abstract}

Kata kunci: Daya, mesin diesel, LPM, jatropha, EGR. 


\section{Pendahuluan}

Salah satu jenis mesin kendaraan bermotor yang sangat sesuai untuk transportasi dan kendaraan alat berat adalah mesin diesel. Kontribusinya untuk kesejahteraan ekonomi, efisiensi pembakaran yang tinggi, kehandalan, fleksibilitas bahan bakar, dan rendahnya konsumsi bahan bakar membuat diesel banyak digunakan di beberapa negara [1]. Meskipun memiliki beberapa keuntungan tersebut, mesin diesel memiliki masalah tentang pencemaran udara yang ditandai dengan adanya asap hitam atau gas buang sisa hasil pemakaran. $\mathrm{NO}_{\mathrm{x}}$ dan $\mathrm{PM}$ (particular matter) merupakan emisi paling tinggi yang dikeluarkan dari hasil sisa pembakaran mesin diesel dibandingkan $\mathrm{HC}$ (hydrocarbon) dan CO (carbonmonoksida) [2].

Bahan bakar diesel merupakan bahan bakar fosil yang tidak dapat diperbaharui karena terbentuknya membutuhkan waktu berjuta-juta tahun lamanya. Biodiesel merupakan bahan bakar alternatif pengganti bahan bakar diesel [3]. Beberapa keuntungan jatropha dapat langsung digunakan pada mesin diesel, dapat dicampur dengan metanol, mempunyai cetane number yang tinggi dan calorific value, serta merupakan sumber energi yang dapat diperbaharui (renewable fuels), dan juga tidak termasuk kategori minyak pangan (non-edible). Kekurangannya mempunyai viskositas yang tinggi serta volatility rendah sehingga sulitnya atom bahan bakar bercampurnya dengan udara dan tingginya emisi smoke, HC dan CO [4]. Sedangkan keuntungan metanol diantaranya, rendah viskositas sehingga dapat dengan mudah diinjeksikan, dikabutkan dan dicampur dengan udara, rendah emisi karena tingginya rasio stokiometri udara dan bahan bakar, serta dapat meningkatkan efisiensi termal mesin [5]. Metanol digunakan juga sebagai aditif campuran bahan bakar yang menyediakan oksigen dan meningkatkan panas penguapan serta berpotensi mereduksi jumlah $\mathrm{NO}_{\mathrm{x}}$ dan PM [3].
Salah satu cara untuk mereduksi tingginya emisi $\mathrm{NO}_{\mathrm{x}}$ yang ditimbulkan mesin diesel dan mengurangi konsumsi bahan bakar digunakan metode EGR (Exhaust Gas Recirculation) [6]. Metode ini dilakukan dengan mensirkulasikan sebagian gas buang ke dalam intake manifold yang kemudian bercampur dengan udara sebelum masuk ke dalam ruang bakar.

Penelitian ini bertujuan untuk mengetahui pengaruh penggunaan metanol kadar rendah (Low Purity Methanol/LPM) saat dipakai sebagai campuran biosolar dan jatropha terhadap daya mesin diesel.

\section{Tinjauan Pustaka}

Daya merupakan besarnya kerja telah dilakukan tiap satuan waktu. Besarnya daya mesin yang diukur dinamakan dengan brake power $(\mathrm{Pb})$. Besarnya daya pengereman dapat diformulasikan sebagai berikut:

$$
\mathrm{P}=\frac{2 \pi N}{60} \times T \times 10^{-3}
$$

dimana $P$ adalah daya $(\mathrm{kW}), T$ adalah torsi (Nm) dan $N$ adalah putaran kerja (rpm) [7].

\section{Metode Penelitian}

Pada penelitian ini dilakukan variasi campuran bahan bakar D85LPM5J10, D80LPM10J10, D75LPM15J10, D75LPM5J20, D70LPM10J20, D65LPM15J20, D65LPM5J30, D60LPM10J30 dan D55LPM15J30. Setiap variasi campuran bahan bakar akan dilakukan pengujian dengan putaran mesin konstan $2000 \mathrm{rpm}$ dengan variasi beban $25 \%, 50 \%, 75 \%$, dan $100 \%$. Pengujian ini juga akan diberikan EGR dengan variasi bukaan dari $0 \%, 25 \%$, dan 50\%. Hal ini bertujuan untuk mengetahui seberapa besar nilai daya yang dihasilkan ketika menggunakan bahan bakar biosolar murni dibandingkan dengan ketika menggunakan campuran bahan bakar biosolar, metanol kadar rendah dan jatropha. Penelitian ini menggunakan mesin diesel 4 silinder, 4 
langkah DI, deskripsi alat uji dapat dilihat pada Gambar 1 dan spesifikasi mesin tampak pada Tabel 1.

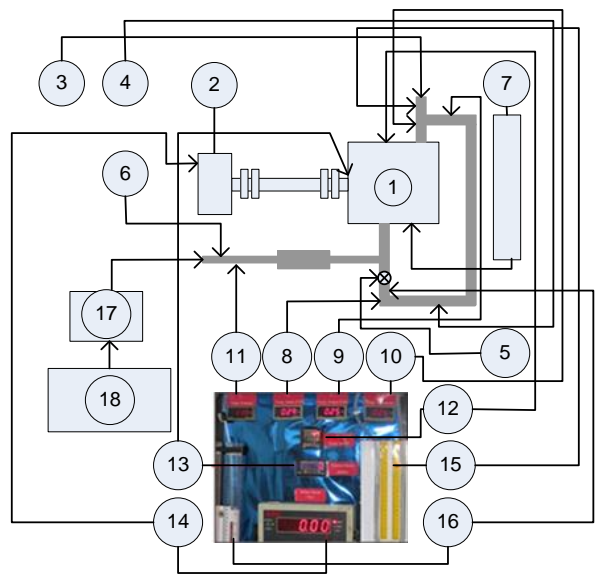

\section{Keterangan:}

1. Mesin diesel

2. Dynamometer

3. Intake manifold

4. Exhaust gas recirculation

5. Katub bukaan $E G R$

6. Exhaust gas

7. Buret

8. Temperatur input EGR

9. Temperatur output EGR

10. Temperatur campuran

11. Temperatur Exhaust gas

12. Temperatur mesin

13. Putaran mesin

14. Beban

15. Manometer udara

16. Manometer $E G R$

17. Smoke meter

18. Opacity

Gambar 1 Deskripsi alat uji

Tabel 1 Spesifikasi Mesin

\begin{tabular}{ll}
\hline \multicolumn{1}{c}{ Spesifikasi } & \multicolumn{1}{c}{ Uraian } \\
\hline Type Motor & $\begin{array}{l}\text { Diesel, OHV, vertical in } \\
\text { line, Direct Injection, } \\
\text { 4JB1 }\end{array}$ \\
\hline $\begin{array}{l}\text { Jumlah } \\
\text { silinder }\end{array}$ & 4 silinder \\
\hline $\begin{array}{l}\text { Diameter } \\
\text { langkah }\end{array}$ & $93 \mathrm{~mm} \times 102 \mathrm{~mm}$ \\
\hline $\begin{array}{l}\text { Volume } \\
\text { silinder }\end{array}$ & $2771 \mathrm{cc}$ \\
\hline $\begin{array}{l}\text { Daya } \\
\text { maksimum }\end{array}$ & $70 / 3000(\mathrm{HP} / \mathrm{rpm})$ \\
\hline $\begin{array}{l}\text { Torsi } \\
\text { maksimum }\end{array}$ & $132 / 2000(\mathrm{lb} . \mathrm{ft} / \mathrm{rpm})$ \\
\hline $\begin{array}{l}\text { Rasio } \\
\text { kompresi }\end{array}$ & $18,2: 1$ \\
\hline
\end{tabular}

Tabel 2 Spesifikasi Bahan Bakar

\begin{tabular}{|c|c|c|c|c|}
\hline $\begin{array}{l}\text { No } \\
\text {. }\end{array}$ & $\begin{array}{l}\text { Paramete } \\
\text { r Uji }\end{array}$ & $\begin{array}{c}\text { Solar } \\
\text { (EURO } \\
\text { II) }\end{array}$ & $\begin{array}{c}\text { Metanol } \\
\text { Kadar } \\
\text { Rendah } \\
\text { (Low } \\
\text { Purity } \\
\text { Methano } \\
\text { l) } \\
\end{array}$ & $\begin{array}{c}\text { Jatroph } \\
\text { a } \\
\text { (minya } \\
\mathrm{k} \\
\text { jarak) }\end{array}$ \\
\hline 1 & $\begin{array}{l}\text { Viskosita } \\
\mathrm{s}\left(40^{\circ} \mathrm{C}\right) \\
\mathrm{cP}\end{array}$ & $2-5$ & 0,46 & 3,23 \\
\hline 2 & $\begin{array}{l}\text { Nilai } \\
\text { Kalor } \\
\text { (J/gr) }\end{array}$ & $\begin{array}{c}45213,8 \\
0\end{array}$ & 21730 & 37968 \\
\hline 3 & $\begin{array}{l}\text { Angka } \\
\text { Cetana }\end{array}$ & 48 & 3,3 & 41,8 \\
\hline 4 & $\begin{array}{l}\text { Flash } \\
\text { Point }{ }^{\circ} \mathrm{C}\end{array}$ & 60 & 10,7 & 198 \\
\hline 5 & $\begin{array}{l}\text { Water } \\
\text { Content } \\
(\% \text { v) }\end{array}$ & 0,05 & 24,88 & 3,16 \\
\hline
\end{tabular}

\section{Hasil dan Pembahasan}

1. Pengaruh EGR terhadap brake power

Pengujian ini dilakukan untuk mengetahui pengaruh EGR terhadap beban dengan katub OEV 0\%, 25\%, 50\%, 75\% dan $100 \%$. Membandingkan EGR dengan tanpa EGR terhadap brake power untuk memperoleh nilai daya maksimal, dilakukan dengan cara membandingkan daya yang dihasilkan dari masing-masing katub OEV. Hasil pengujian pengaruh EGR terhadap brake power ditunjukkan pada Gambar 2 s/d Gambar 11.

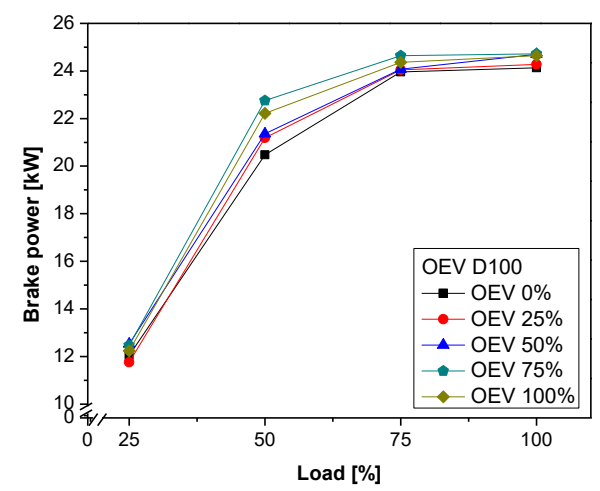

Gambar 2. Pengaruh EGR terhadap brake power dengan variasi beban menggunakan bahan bakar D100. 


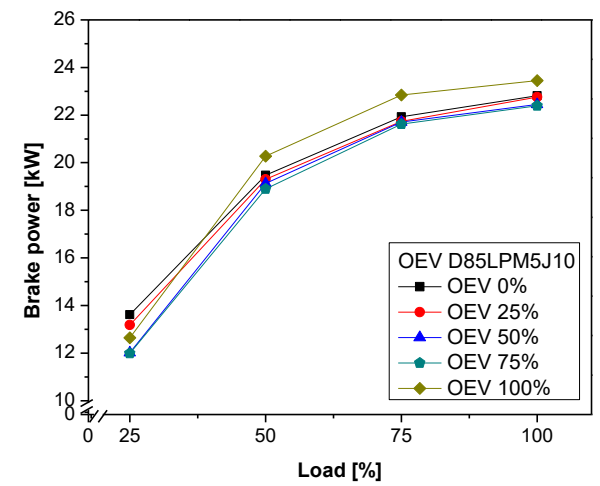

Gambar 3. Pengaruh EGR terhadap brake power dengan variasi beban menggunakan bahan bakar D85LPM5J10.

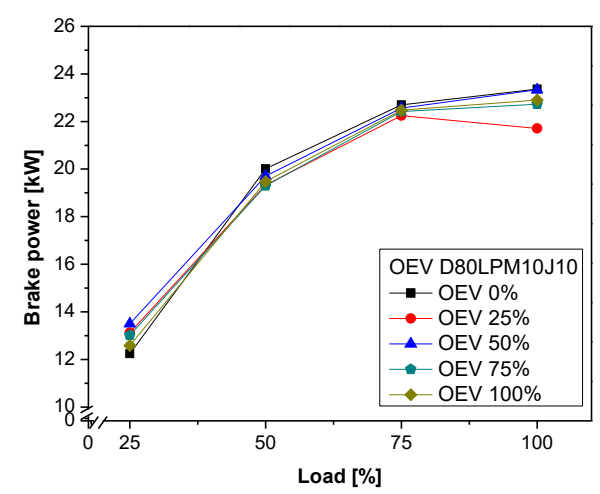

Gambar 4. Pengaruh EGR terhadap brake power dengan variasi beban menggunakan bahan bakar D80LPM10J10.

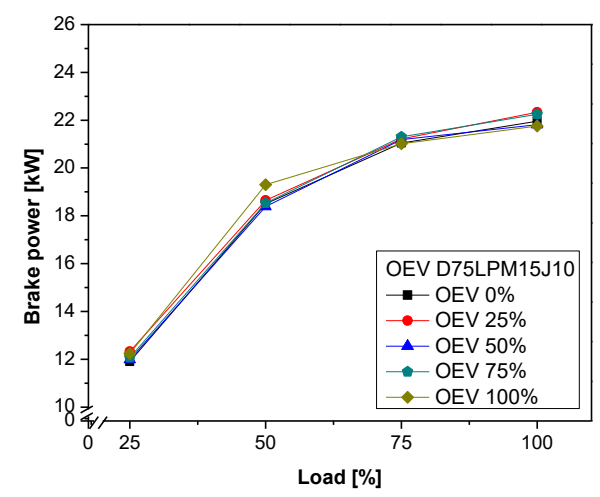

Gambar 5. Pengaruh EGR terhadap brake power dengan variasi beban menggunakan bahan bakar D75LPM15J10.

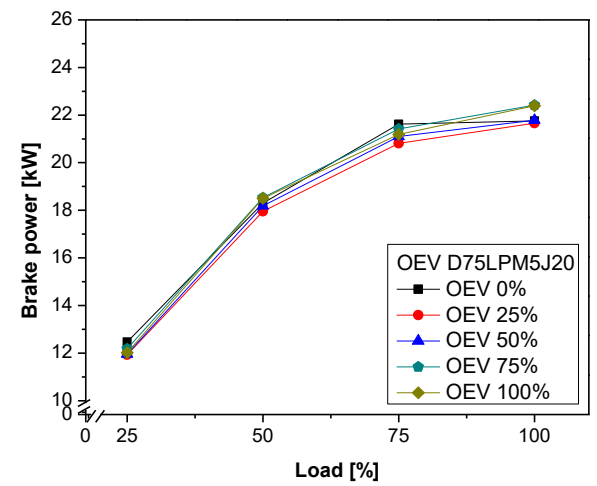

Gambar 6. Pengaruh EGR terhadap brake power dengan variasi beban menggunakan bahan bakar D75LPM5J20.

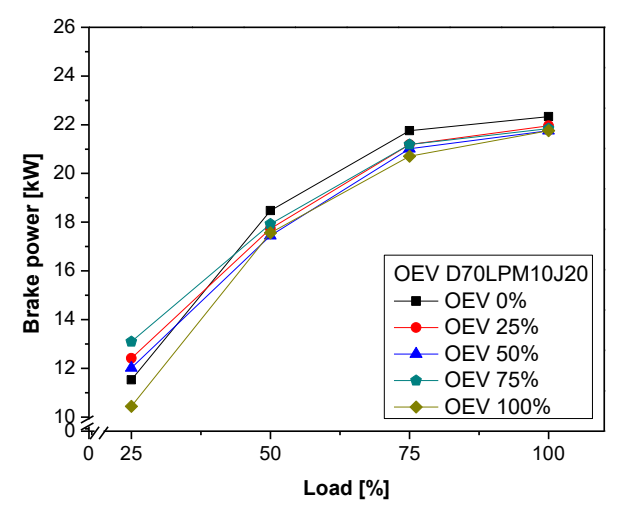

Gambar 7. Pengaruh EGR terhadap brake power dengan variasi beban menggunakan bahan bakar D70LPM10J20.

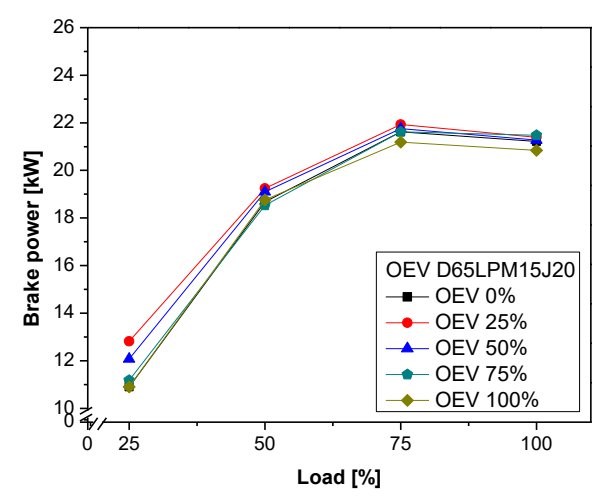

Gambar 8. Pengaruh EGR terhadap brake power dengan variasi beban menggunakan bahan bakar D65LPM15J20. 


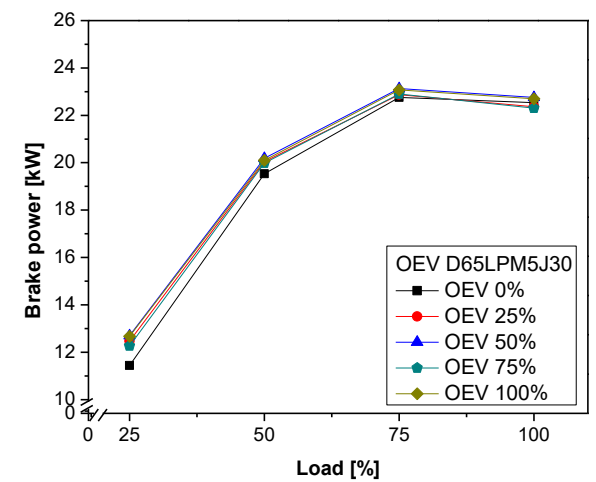

Gambar 9. Pengaruh EGR terhadap brake power dengan variasi beban menggunakan bahan bakar D65LPM5J30.

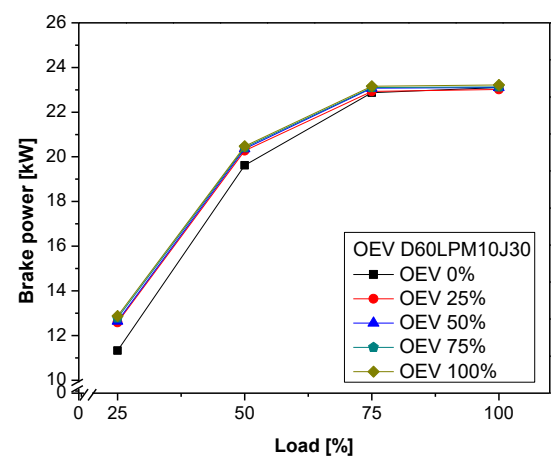

Gambar 10. Pengaruh EGR terhadap brake power dengan variasi beban menggunakan bahan bakar D60LPM10J30.

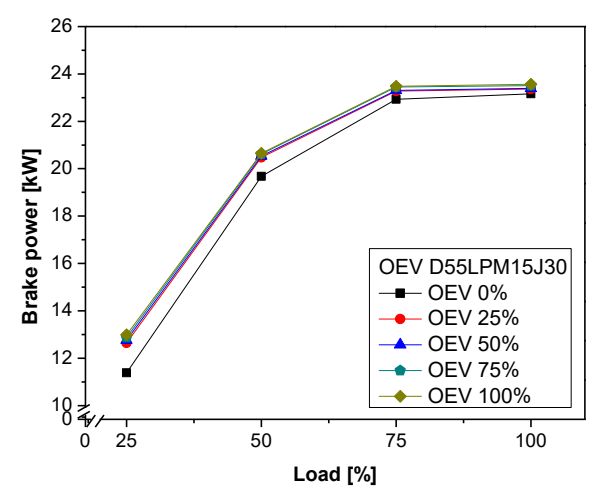

Gambar 11. Pengaruh EGR terhadap brake power dengan variasi beban menggunakan bahan bakar D55LPM15J30.

Gambar 2 s/d Gambar 11 menyatakan pengaruh EGR terhadap brake power untuk berbagai beban. Warna hitam persegi untuk tanpa EGR, warna merah lingkaran untuk katub OEV 25\%, warna biru segitiga untuk katub OEV 50\%, warna hijau gelap segilima untuk katub OEV $75 \%$, warna kuning gelap belah ketupat untuk katub OEV 100\%. Nilai brake power meningkat dengan meningkatnya beban [7].

Dari gambar 2 bahan bakar D100, nilai brake power juga meningkat ketika menggunakan EGR pada semua beban. Hal ini dikarenakan sebagian gas buang yang disirkulasikan mengakibatkan peningkatan temperature intake, sebagai akibatnya tekanan intake meningkat sehingga mengakibatkan peningkatan tekanan untuk menghasilkan daya [8], dan juga dikarenakan EGR dapat meningkatkan kalor jenis daripada udara segar, serta naiknya kalor jenis mengakibatkan energi yang dihasilkan meningkat [9]. Nilai brake power tertinggi terjadi pada katub OEV $75 \%$, pada beban $50 \%$, dan $100 \%$ sebesar $10.29 \%, 2.41 \%$. Akan tetapi untuk bahan bakar D85LPM5J10 tampak Gambar 3, nilai brake power turun ketika menggunakan EGR pada semua beban dikarenakan jumlah udara segar yang masuk ke ruang bakar berkurang sehingga konsentrasi $\mathrm{O}_{2}$ menurun mengakibatkan temperatur di ruang bakar menurun dan tekanan menjadi rendah, maka kerja yang dilakukan piston diruang bakar ikut berkurang untuk menghasilkan daya [9]. Terjadi penurunan nilai brake power katub OEV $100 \%$ pada beban $25 \%$ sebesar $12.47 \%$ dibandingkan tanpa EGR, tetapi untuk beban $50 \%$ s/d $100 \%$ nilai brake power meningkat terjadi pada katub OEV $100 \%$ pada beban $100 \%$ sebesar $2.74 \%$.

Pada Gambar 4 untuk bahan bakar D80LPM10J10, dengan menggunakan EGR nilai brake power cenderung turun untuk beban $50 \%$ s/d 100\%, besar penurunannya sebesar $9.71 \%$ terjadi pada beban $100 \%$ katub OEV 25\%. Pada beban rendah terjadi kenaikan nilai brake power katub OEV $100 \%$ pada beban $25 \%$ sebesar 7.26\%. Sedangkan pada Gambar 5 untuk bahan bakar D75LPM15J10, penggunaan EGR tidak berpengaruh signifikan terhadap tanpa EGR. Nilai brake power tertinggi terjadi pada katub OEV $25 \%$ pada beban $100 \%$. Terjadi sedikit kenaikan nilai daya 
katub OEV 100\% dibandingkan tanpa EGR pada beban $50 \%$ sebesar $4.26 \%$.

Untuk penambahan jatropha $20 \%$, bahan bakar D75LPM5J20 Gambar 6 nilai brake power sedikit menurun ketika menggunakan EGR untuk beban 25\%-75\%, tetapi terjadi kenaikan pada OEV $75 \%$ $100 \%$ pada beban $100 \%$. Nilai brake power tertinggi terjadi pada katub OEV $75 \%$ pada beban $100 \%$ sebesar 3\%. Sama halnya D70LPM10J20 pada Gambar 7 penggunaan EGR mengakibatkan penurunan nilai brake power pada beban $50 \%-100 \%$, tetapi pada beban rendah nilai brake power terjadi peningkatan sebesar $12.52 \%$ pada katub OEV $75 \%$. Nilai brake power tertinggi terjadi pada tanpa EGR sebesar $2.62 \%$ apabila dibandingkan dengan katub OEV 100\% untuk beban tinggi. Akan tetapi untuk bahan bakar D65LPM15J20 pada Gambar 8 nilai brake power sedikit meningkat ketika penggunaan EGR untuk berbagai beban. Pada beban rendah terjadi peningkatan brake power sebesar $15.61 \%$ katub OEV $25 \%$, sedangkan penurunan brake power untuk katub OEV $100 \%$ pada beban $75 \%$ $100 \%$. Terjadi penurunan katub OEV $100 \%$ pada beban $100 \%$ sebesar $1.79 \%$.

Begitupun sama dengan D100, penggunaan jatropha $30 \%$ menyebabkan kenaikan nilai brake power ketika penambahan katub untuk semua beban dibandingkan tanpa EGR. Saat menggunakan bahan bakar D65LPM5J30 tampak pada Gambar 9, nilai brake power tertinggi terjadi pada katub OEV 50\% pada beban rendah sebesar $10.35 \%$, tetapi untuk beban tinggi terjadi sedikit penurunan nilai brake power katub OEV $75 \%$ pada beban $100 \%$ yaitu $1.04 \%$. Ketika menggunakan bahan bakar D60LPM10J30 nilai brake power tertinggi terjadi pada katub OEV $100 \%$ pada beban $25 \%$ sebesar $12.52 \%$ dan pada beban $100 \%$ tidak berpengaruh signifikan. Kemudian menggunakan bahan bakar D55LPM15J30 nilai brake power tertinggi terjadi pada katub OEV $100 \%$ pada beban $25 \%$ dan $100 \%$ sebesar $12.87 \%$ dan $1.73 \%$.
2. Pengaruh variasi campuran bahan bakar terhadap brake power

Pengujian ini dilakukan untuk mengetahui pengaruh bahan bakar terhadap brake power dengan variasi campuran bahan bakar yaitu D85LPM5J10, D80LPM10J10, D75LPM15J10, D75LPM5J20, D70LPM10J20, D65LPM15J20, D65LPM5J30, D60LPM10J30 dan D55LPM15J30. Hasil pengujian dari masing-masing bahan bakar tersebut dibandingkan dengan D100 untuk mendapatkan nilai maksimum dan minimum dari perubahan daya. Sedangkan untuk memperoleh nilai daya maksimum, didapatkan dengan membandingkan nilai daya yang dihasilkan dari masing-masing bahan bakar. Hasil pengujian pengaruh bahan bakar terhadap brake power ditunjukkan pada Gambar 12 s/d Gambar 16.

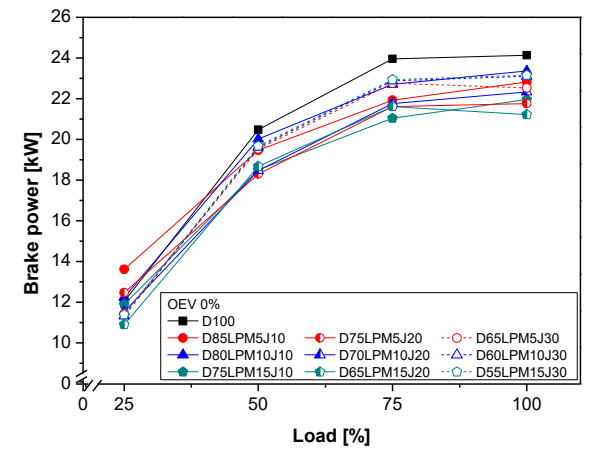

Gambar 12. Pengaruh campuran bahan bakar terhadap brake power dengan variasi beban menggunakan OEV $0 \%$.

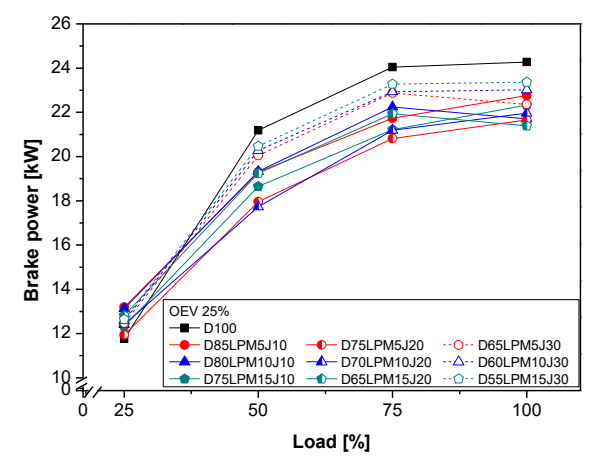

Gambar 13. Pengaruh campuran bahan bakar terhadap brake power dengan variasi beban menggunakan OEV $25 \%$. 


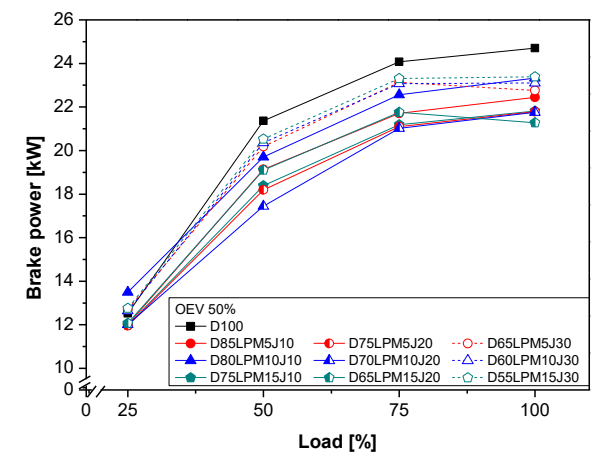

Gambar 14. Pengaruh campuran bahan bakar terhadap brake power dengan variasi beban menggunakan OEV 50\%.

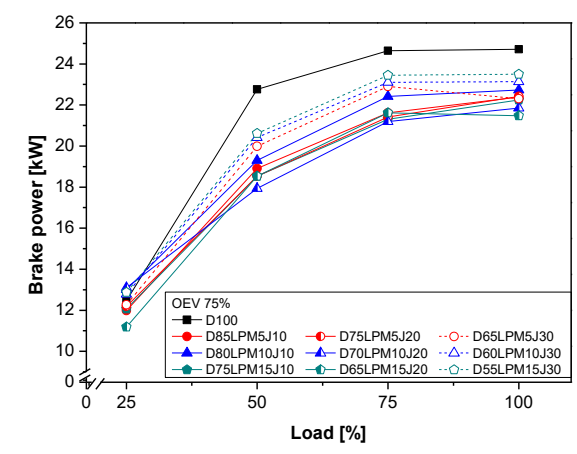

Gambar 15. Pengaruh campuran bahan bakar terhadap brake power dengan variasi beban menggunakan OEV $75 \%$.

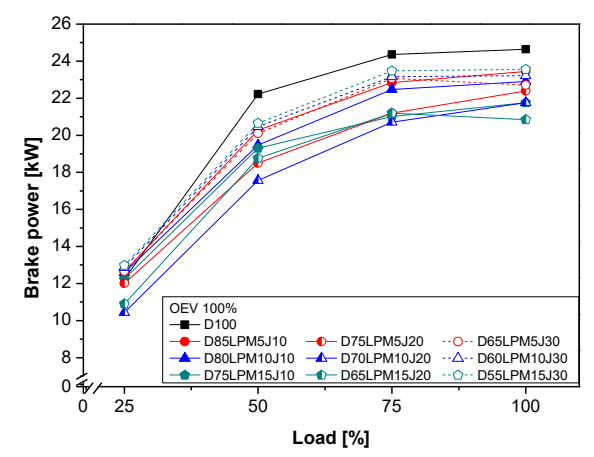

Gambar 16. Pengaruh campuran bahan bakar terhadap brake power dengan variasi beban menggunakan bukaan katub 100\%.

Gambar 12 s/d Gambar 16 menunjukkan nilai brake power meningkat dengan meningkatnya beban [7]. Campuran bahan bakar diesel-LPM-jatropha mengakibatkan menurunnya nilai brake power. Hal ini dikarenakan heating value yang rendah dibandingkan diesel fuel [1, 10]. Penambahan jatropha menyebabkan turunnya nilai brake power disebabkan heating value yang rendah [11].

Pada Gambar 12 menunjukkan pengaruh campuran bahan bakar terhadap brake power dengan tanpa EGR cenderung turun, kecuali pada beban $25 \%$. Nilai brake power tertinggi terjadi pada bahan bakar D100. Penurunan nilai brake power tertinggi pada campuran bahan bakar D65LPM15J20 dibanding D100 pada beban $100 \%$ sebesar $12.36 \%$. Kenaikan nilai brake power pada campuran bahan bakar D85LPM5J10 pada beban 25\% sebesar $12.03 \%$.

Sama halnya tanpa EGR, ketika menggunakan katub OEV 25\% ditunjukkan pada Gambar 13 nilai brake power cenderung turun, kecuali pada beban rendah. Nilai brake power tertinggi terjadi pada bahan bakar D100. Penurunan nilai brake power tertinggi terjadi pada D65LPM15J20 dibanding D100 pada beban $100 \%$ sebesar $12.16 \%$. Terjadi kenaikan nilai brake power pada campuran bahan bakar D85LPM5J10 untuk beban rendah sebesar $11.31 \%$.

Seperti katub OEV 25\%, untuk katub OEV 50\% pada Gambar 14 memperlihatkan pengaruh campuran bahan bakar terhadap brake power cenderung menurun kecuali pada beban $25 \%$. Nilai brake power tertinggi terjadi pada bahan bakar D100. Nilai brake power turun pada beban $100 \%$ sebesar $14.20 \%$ untuk D65LPM15J20 dibanding D100. Kenaikan nilai brake power pada campuran bahan bakar D80LPM10J10 pada beban $25 \%$ sebesar $7.50 \%$.

Sama seperti katub OEV 50\%, pada katub OEV $75 \%$ hasil pengujian pada Gambar 15 menunjukkan pengaruh campuran bahan bakar terhadap brake power turun, kecuali pada beban $25 \%$. Nilai brake power tertinggi terjadi pada bahan bakar D100. Nilai brake power turun pada campuran bahan bakar D65LPM15J20 dibanding D100 pada beban $100 \%$ sebesar $13.41 \%$. Pada campuran bahan bakar D70LPM10J20 nilai brake power meningkat pada beban $25 \%$ sebesar $5.01 \%$. 
Sama halnya ketika katub OEV 75\%, katub OEV $100 \%$ tampak pada Gambar 16 diperlihatkan pengaruh campuran bahan bakar terhadap brake power cenderung menurun kecuali pada beban rendah. Nilai brake power tertinggi terjadi pada bahan bakar D100. Terjadi penurunan tertinggi nilai brake power pada campuran bahan bakar D65LPM15J20 dibandingkan dengan D100 pada beban $100 \%$ sebesar $11.98 \%$. Nilai brake power terjadi kenaikan pada beban rendah sebesar $5.97 \%$ untuk campuran bahan bakar D55LPM15J30.

\section{Kesimpulan}

Pengunaan EGR mengakibatkan meningkatkan nilai brake power. Pengaruh campuran bahan bakar menyebabkan nilai brake power cenderung turun dibandingkan D100. Ketika menggunakan D85LPM5J10, D80LPM10J10, D70LPM10J20 dan D55LPM15J30 pada beban rendah (25\%) terjadi kenaikan daya sebesar $12.03 \%$, $7.50 \%, 5.01 \%$, dan $5.97 \%$.

\section{Ucapan terimakasih}

Penulis mengucapkan terima kasih kepada laboran di laboratorium thermofluid UNDIP, departemen Teknik mesin Universitas Diponegoro dan prodi teknik mesin Universitas Muhammadiyah Tangerang, sehingga penelitian ini dapat diselesaikan.

\section{Referensi}

[1]. Zhiqiang Guo, Tianrui Li, "Combustion and emission characteristic of blends of diesel fuel and metanol to diesel", International Journal of Fuel, Number 90, ScienceDirect, 2011.

[2]. Asif Faiz, Walsh Michael P, Weaver Christopher S,"Air Pollution From Motor Vehicles, Standards and Technologies for Controlling Emissions", The World Bank Washington, D.C, USA, 1996.
[3]. Lei Zhu, C.S. Cheung, W.G. Zhang, Zhen Huang,"Emissions characteristic of a diesel engine operating on biodiesel and biodiesel blended with ethanol and metanol", International Journal of the Total Enviroment, Number 408, ScienceDirect, 2010.

[4]. M. Senthil Kumar, A. Ramesh, B. Nagalingham, 2003, "An

Experimental Comparison of Methods to Use Metanol and Jatropha Oil in a Compression Ignition Engine", Department of Mechanical Engineering, Indian Institute of Technology Madras, Chennai, India.

[5]. Cenk Sayin, Ahmet Necati, Mustafa Canakci, 2009, "The Influence of operating parameters on the performance and emissions of a DI diesel engine using metanol-blendeddiesel fuel", International Journal of Fuel, Number 89, ScienceDirect.

[6]. Vinod Singh Yadav, "Perfomance and emission studies of direct injection C.I. engine in duel fuel mode (hydrogen-diesel) with EGR", International Journal of Hydrogen energy, Number 37, ScienceDirect, 2012.

[7]. Heywood, John B.L, 1988, "Internal Combustion Engine Fundamentals”, McGraw-Hill, Inc, United States of America.

[8]. V. Pradeep, R.P. Sharma, 2007, “Use of HOT EGR for NOx control in a compression ignition engine fuelled with bio-diesel from Jatropha oil", International Journal of Renewable energy, Number 32, ScienceDirect.

[9]. Avinash Kumar Agrawal, Shrawan Kumar Singh, Shailendra Sinha and Mritunjay Kumar Shukla, 2003, "Effect of EGR on the Exhaust Gas Temperature and Exhaust Opacity in 
Compression Ignition Engines", Kanpur 208 016, India.

[10]. Philip Kristanto \& Ricky Winaya, 2003, "Penggunaan Minyak Nabati Sebagai Bahan Bakar Alternatif Pada Motor Diesel Sistim Injeksi Langsung", Jurnal Teknik Mesin Volume 5 Nomor 1. 